\title{
PEMBINAAN KEBERAGAMAAN DAN KEILMUAN \\ GENERASI MUDA DI MADRASAH DINIYAH ATTAQWA DESA CISONTROL KABUPATEN CIAMIS TAHUN 1983-1989
}

\author{
Widiati Isana \\ Dosen Sejarah Peradaban Islam Fakultas Adab dan Humaniora \\ UIN Sunan Gunung Djati Bandung \\ (isanawidiati@yahoo.co.id)
}

\begin{abstract}
This study aims at determining the profile of Madrasah Diniyah Attaqwa (MDA) in 1983-1989, the role of MDA in fostering religious and scientific spirit of young people in 1983-1989, and the pattern of fostering that has carried out in raising of religious and scientific spirit of young villagers in Cisontrol in 1983-1989. This research is started off the framework that Madrasah Diniyah as Islamic educational institutions must be able to do a planned and deliberate coaching and guiding in order to achieve integrated personality, the personality of Muslims, the totality of the physical, spiritual, and moral sense. This research uses the historical method. Type of data is qualitative and data collection techniques through interviews, documents, and literature. The results showed that the religious and scientific spirit of young villagers in Cisontrol Ciamis in 1983-1989 cannot be separated from the great role of MDA. The emergence of religious and scientific spirit is due to the fact that MDA's profile is full of simplicity but keep a lot of achievements, the role of MDA gives spirit of strugle and uphold of Islamic teachings, as well as MDA's fostering patterns give noticiable benefits.
\end{abstract}

Keyword: Islamic Primary School, fostering religious, scientific spirit, young generation.

\section{PENDAHULUAN}

Pembinaan manusia supaya menjadi manusia yang kreatif dan produktif, salah satunya bisa melalui pendidikan agama, karena peranan pendidikan agama khususnya bagi kalangan anak-anak dan remaja merupakan dasar untuk membentengi dirinya dari zaman yang penuh problem dan tantangan. Tidak hanya ditekankan pada segi penguasaan hal-hal yang bersifat kognitif atau pengetahuan ajaran agama saja, tapi justru yang lebih penting penanaman nilai-nilai keagamaan dan membuatnya terwujud nyata dalam tingkah laku dan budi pekerti seharihari. Menurut Nurcholish Madjid, pendidikan agama yang sarat dengan sistem nilai, berkisar pada dua dimensi hidup, yaitu penanaman rasa taqwa kepada Allah, dan pengembangan rasa kemanusiaan (Andi Hakim Nasution, dkk, 2001:31).

Penanaman rasa taqwa kepada Allah sebagai dimensi pertama hidup, dimulai dengan penanaman 
nilai-nilai keagamaan yang sangat mendasar yaitu keimanan atau aqidah. Dimana iman adalah sikap batin yang penuh kepercayaan kepada Tuhan (Andi Hakim Nasution, dkk, 2001: 34). Dalam hal ini tidak cukup hanya "percaya" kepada adanya Tuhan, melainkan harus meningkat menjadi sikap "mempercayai" Tuhan dan "menaruh kepercayaan" kepada-Nya. Tentu masih banyak lagi nilai-nilai keagamaan yang harus ditanamkan dan diajarkan dalam Islam. Pengembangan dimensi yang kedua dalam kehidupan yaitu rasa kemanusiaan. Patut kita renungkan sabda Nabi bahwa "Yang paling memasukan orang kedalam surga ialah taqwa kepada Allah dan keluhuran budi" (Andi Hakim Nasution, dkk, 2001: 36). Nilai-nilai kemanusiaan yang bisa ditanamkan diantaranya: silaturahmi, persaudaraan, sedekah, sabar, pemaaf dan lain-lain.

Kedua dimensi diatas, erat kaitannya antara taqwa dan budi luhur, atau antara iman dan amal shalih. Dalam pengertian lain terdapat keterkaitan antara Ketuhanan sebagai dimensi hidup pertama manusia yang vertikal (garis ke atas), dengan Kemanusiaan sebagai dimensi kehidupan manusia yang horizontal (garis mendatar). Maka pendidikan agama belum dikatakan berhasil kecuali jika pada anak didik tertanam dan tumbuh dengan baik kedua nilai itu, yaitu Ketuhanan dan Kemanusiaan, atau Taqwa dan Budi Luhur. Untuk merealisasikan kedua dimensi diatas terhadap anak dan remaja, bukan hal yang mudah, tetapi juga jangan terkurung dengan rasa pesimis. Anak dan remaja adalah cerminan bangsa di masa depan. Mereka adalah bagian dari masa kini dan keseluruhan di hari esok. Zaman terus berubah dan peradaban pun terus berkembang dengan segala problema dan tantangannya. Proses alih generasi pun terus berlangsung. Karena itu, sikap pesimis yang berlebihan bukan pada tempatnya. Masih banyak ruang untuk melihat sisi optimisme dari kalangan generasi anak dan remaja yang menjanjikan untuk menjadi penerus di masa depan.

Keberadaan madrasah yang formal, diakui memberikan sumbangan penting bagi perkembangan ilmu pengetahuan, begitu pun dengan Madrasah Diniyah, sebagai salah satu lembaga pendidikan, bisa dijadikan solusi sebagai wadah untuk menyiapkan generasi penerus di masa depan yang bertaqwa dan berbudi luhur. Zainudin Labai mengung-kapkan bahwa Madrasah Diniyah merupakan madrasah sore untuk pendidikan agama yang diorganisasikan berdasarkan sistem klasikal dan tidak mengikuti sistem pengajian tradisional yang individual (Steenbrink, 1994: 44). Dengan kata lain Madrasah Diniyah adalah sebagai lembaga pendidikan Islam non-formal yang memiliki peranan penting dan lebih komfrehensif dalam mencetak generasi muda yang akan datang.

Untuk mencetak generasi muda yang Islami, spiritualitas, moralitas dan kerukunan dalam keberagamaan merupakan hal yang utama. Tiga landasan hidup tersebut mulai memudar dan sering menjadi bencana sosial di lingkungan masyarakat. Dengan mengembalikan ketiga nilai tersebut melalui langkah strategis berupa penguatan internal kelembagaan Madrasah Diniyah, 
Pembinaan Keberagamaan dan Keilmuan

semoga bisa kembali meraih apa yang telah hilang dari kesadaran masyarakat dan menjadikannya sebagai karakter pribadi bangsa Indonesia yang moralis, mandiri dan dengan kualifikasi Imtaq dan Iptek sesuai dengan slogan yang selalu disuarakan.

Upaya untuk meraih karakter pribadi bangsa yang moralis, mandiri dengan kualifikasi Imtaq dan Iptek, Desa Cisontrol Kabupaten Ciamis memiliki wadah untuk pembinaan ke arah itu yaitu Madrasah Diniyah Attaqwa. Keberadaan Madrasah Diniyah Attaqwa di Desa Cisontrol merupakan wadah yang memberikan pencerahan tentang keberagamaan dan keilmuan masyarakatnya, khusus para generasi muda. Berdirinya MDA (penyebutan Madrasah Diniyah Attaqwa selanjutnya) mengundang perhatian berbagai kalangan, karena di Desa Cisontrol MDA merupakan Madrasah Diniyah yang pertama kali berdiri. Hampir semua generasi Muda Desa Cisontrol terutama mereka yang menduduki bangku sekolah SD dan SMP datang berduyun-duyun untuk belajar di MDA, dan mereka menamakannya "Sakola Agama".

Perkembangan MDA yang terus maju, baik dari segi kuantitas maupun kualitas, mengundang banyak perubahan-perubahan yang signifikan dikalangan generasi muda pada saat itu, khususnya dalam keberagamaan dan keilmuannya. Ilmu yang mereka dapatkan di MDA, mereka amalkan dan diaktualisasikan dalam kehidupannya. Keberadaan MDA menginspirasi masing-masing kampung untuk mendirikan Madrasah Diniyah Sendiri. Sehingga yang tadinya proses pembelajaran terpokus di MDA, akhirnya mereka belajar di Madrasah Diniyah kampung masing-masing. Oleh karena itu rentang waktu antara 1983-1989 MDA mengukir sejarah yang tidak akan terlupakan di Desa Cisontrol.

Semangat generasi muda yang belajar di MDA untuk mengaktualisasikan dan mengamalkan ajaran-ajaran Islam berdasarkan al-Qur'an dan Sunah Rasul terlihat dari indikasi-indikasi diantaranya dengan keyakinannya mencoba membangun diri dan lingkungannya dengan suasana religius. Misalnya ketika lembagalembaga pendidikan umum tidak memberlakukan siswanya untuk memakai jilbab, justru mereka yang belajar di MDA menjadi pionir, teladan dalam mengawali pemakaian jilbab di sekolah-sekolah mereka. Banyak tantangan yang dihadapi diawal perjuangan menegakkan syari'at itu, tetapi tidak membuat gentar, justru lebih semangat mengobarkan api perjuangan menegakan ajaran Islam. Selain indikasi dari semangat keberagamaan yang muncul, MDA juga memberikan pelayanan kepada generasi muda dalam meningkatkan kualitas keilmuan di berbagai bidang. Keilmuan yang dikembangkan oleh MDA selain ilmu-ilmu yang disampaikan pada jam belajar, juga mengembangkan keilmuan dalam seni suara/Qasidah, Kaligerafi/seni menulis huruf arab, olahraga, koperasi, dan sosial kemasyarakatan. Dari pengalaman mereka belajar berbagai keilmuan memberikan semangat dan motivasi untuk terus mencari ilmu. Hasil wawancara dan beberapa sumber yang diperoleh, keberadaan MDA memberikan peran besar dalam memotivasi semangat keberagamaan dan keilmuan mereka. Semangat keberagamaan dan 
keilmuan yang mereka bangun ternyata sangat berpengaruh kepada kehidupan mereka sampai sekarang.

Dari latar belakang MDA yang telah diuraikan di atas, memberikan gambaran betapa besar pembinaan dalam semangat keberagamaan dan keilmuan generasi muda yang dilakukan oleh Madrasah Diniyah Attaqwa Desa Cisontrol Kabupaten Ciamis. Hal ini tentu di dukung oleh berbagai faktor, baik program-program kajian keilmuan yang diberikan, pembinaan dan pengkaderan guru-guru yang berkualitas serta pola-pola pembinaan dan manajemen yang dilakukan di MDA. Kondisi MDA yang demikian, menarik untuk diteliti lebih jauh. Oleh karena itu dalam penelitian ini difokuskan pada persoalan bagaimana Pembinaan semangat keagamaan dan keilmuan generasi Muda di Madrasah Diniyah Attaqwa Desa Cisontrol Kabupaten Ciamis. Oleh karena itu rumusan masalahnya berkisar pada persoalan: a) Bagaimana profil Madrasah Diniyah Attaqwa Desa Cisontrol Kabupaten Ciamis?, b) Bagaiman peranan Madrasah Diniyah Attaqwa dalam membina semangat keberagamaan dan keilmuan generasi Muda Desa Cisontrol Kabupaten Ciamis?, dan c) Bagaimana Pola pembinaan yang dilakukan Madrasah Diniyah Attaqwa dalam meningkatkan semangat keberagamaan dan keilmuan generasi muda Desa Cisontrol Kabupaten Ciamis.

\section{Landasan Teori}

Diawali dengan informasi mengenai madrasah, pada sesi ini informasi mengenai kerangka pemikiran turut membingkai pentingnya penelitian ini. Kata "madrasah" dalam bahasa arab adalah bentuk kata "keterangan tempat" ( zharaf makan ) dari akar kata "darasa". Secara harfiah " madrasah" diartikan sebagai "tempat belajar para pelajar", atau "tempat untuk memberikan pelajaran" (www.ziddu.com). Dari akar kata " darasa" juga bisa diturunkan kata "madras" yang mempunyai arti "buku yang dipelajari" atau " tempat belajar"; kata "al-midras" juga diartikan sebagai "rumah untuk mempelajari kitab taurat". Kata "madrasah" juga ditemukan dalam bahasa Hebrew atau Aramy, dari akar kata yang sama yaitu "darasa" yang berarti "membaca dan belajar" atau "tempat duduk untuk belajar". Dari kedua bahasa tersebut, kata"madrasah" mempunyai arti yang sama : "tempat belajar". Jika diterjemahkan ke dalam bahasa Indonesia, kata, "madrasah" memiliki arti " sekolah" kendati pada mulanya kata "sekolah" itu sendiri bukan berasal dari bahasa Indonesia, melainkan dari bahasa asing, yaitu school atau scola (www.ziddu.com).

Madrasah Diniyah dilihat dari struktur bahasa arab berasal dari dua kata Madrasah dan Al-din. Kata Madrasah dijadikan nama tempat, dari asal kata darosa yang berarti belajar. Jadi Madrasah mempunyai makna tempat belajar. Sedangkan $A l$ din dimaknai dengan makna keagamaan. Dari dua struktur kata yang dijadikan satu tersebut, Madrasah Diniyah berarti tempat belajar masalah keagamaan, dalam hal ini agama Islam (www.ziddu.com). Madrasah Diniyah adalah lembaga pendidikan yang memberikan pendidikan dan pengajaran secara klasikal yang bertujuan untuk memberi tambahan pengetahuan agama islam kepada 
Pembinaan Keberagamaan dan Keilmuan Generasi Muda di Madrasah Diniyah Attaqwa Desa Cisontrol Kabupaten Ciamis Tahun 1983-1989

pelajar-pelajar yang merasa kurang menerima pelajaran agama Islam. Sehingga diharapkan dengan belajar di Madrasah Diniyah masyarakat Indonesia khususnya generasi muda akan memiliki karakter pribadi yang moralis, mandiri dengan kualifikasi Imtaq dan Iptek. Untuk mewujudkan masyarakat Indonesia yang moralis, mandiri dengan kualifikasi Imtaq dan Iptek, maka Madrasah Diniyah banyak berperan sebagai lembaga pendidikan Islam yang mengusung kebutuhan-kebutuhan masyarakat disekitarnya terutama dalam membina keimanan dan ketaqwaan.

Berdasarkan Undang-undang Pendidikan dan Peraturan pemerintah no 73 tahun 1991 pada pasal 1 ayat 1 disebutkan "Penyelenggaraan pendidikan diluar sekolah boleh dilembagakan dan boleh tidak dilembagakan". Madrasah Diniyah adalah bagian terpadu dari system pendidikan nasional yang diselenggarakan pada jalur pendidikan luar sekolah untuk memenuhi hasrat masyarakat tentang pendidikan agama. Madarsah Diniyah termasuk kelompok pendidikan keagamaan jalur luar sekolah yang dilembagakan dan bertujuan untuk mempersiapkan peserta didik menguasai pengetahuan agama Islam, yang dibina oleh Menteri Agama (PP 73, Pasal 22 ayat 3). Oleh karena itu, maka Menteri Agama dan Direktorat Jenderal Pembinaan Kelembagaan Agama Islam menetapkan Kurikulum Madrasah Diniyah dalam rangka membantu masyarakat mencapai tujuan pendidikan yang terarah, sistematis dan terstruktur. Meskipun demikian, masyarakat tetap memiliki keleluasaan untuk mengembangkan isi pendidikan, pendekatan dan muatan kurikulum sesuai dengan kebutuhan dan lingkungan madrasah.

Pengertian kata madrasah di atas tidak dapat terlepas dari istilah keberagamaan. Pengertian keberagamaan dan keilmuan bisa dilihat dari akar katanya terlebih dahulu. Secara harfiah term beragama berasal dari akar kata Agama dan kata kerjanya beragama yang berarti menjalankan atau melaksanakan ajaran agama (http:// achakim.blogspot.com). Sedangkan keilmuan akar katanya adalah ilmu yang secara etimologi berarti tahu atau pengetahuan (http://id.shvoong.com). Dengan kata lain Ilmu bisa berarti proses memperoleh pengetahuan, atau pengetahuan terorganisasi yang diperoleh lewat proses tersebut. Proses keilmuan adalah cara memperoleh pengetahuan secara sistematis tentang suatu sistem.

Agama adalah seperangkat ajaran yang diturunkan dari Tuhan melalui Nabi dan Rasul-Nya sebagaimana dimuat dalam AlQur'an dan Sunnah. Sedangkan keberagamaan adalah respon atau pandangan seseorang atas ajaran agama yang dia anut atau dia yakini (http:// achakim.blogspot.com). Sehingga apa yang dilakukan dalam rangka menjalankan ajaran agama itu merupakan keberagamaan. Dari pengertian tersebut, semangat keberagamaan adalah motivasai yang tinggi untuk menjalankan ajaran agama yang diyakininya. Dan semangat keilmuan menunjukan pengertian tentang motivasi yang tinggi untuk mendalami ilmu pengetahuan.

Selain itu, penelitian ini didasarkan juga pada kerangka pemikiran bahwa manusia mempunyai kebebasan berkehendak 
dan berbuat, dan berdasarkan kebebasan kehendaknya itulah, manusia bertanggung jawab terhadap hasil perbuatannya (Afif Muhammad, 2004: 184). Pandangan tentang keberadaan manusia seperti tersebut, menuntut adanya sebuah ikhtiar yang ampuh untuk membantu subyek didik supaya bisa berkembang secara normatif dan lebih baik (Ahmad Tafsir, 1995: 35). Maka, pendidikan menurut konsep Islam adalah pendidikan yang diarahkan pada upaya optimalisasi potensi dasar manusia secara keseluruhan. Pendidikan bukan semata-mata diarahkan pada upaya penumbuhan dan pengembangan manusia secara biologis-fisiologis yang lebih menekankan pada pengayaan secara material, seperti ditunjukkan pada praktek pendidikan yang lebih menekankan domain kognitif dan psikomotorik. Demikian juga, pendidikan bukan hanya pengayaan aspek mental-spiritual dalam rangka mengejar tujuan normatif (domain afektif) demi tercapainya manusia yang baik (shalih) secara etik dan moral serta kepekaan susila, sementara tidak diimbangi oleh profesionalitas.

Muatan pendidikan yang mementingkan salah satu aspek saja hanya akan menghasilkan kepribadian yang pecah (split of personality), (Muhammad Irfan \& Mastuki HS, 2000: 143). Karena itu, salah satu prinsip sistem pendidikan Islam adalah keharusan untuk menggunakan metode pendekatan yang menyeluruh terhadap manusia: meliputi dimensi jasmani-ruhani dan semua aspek kehidupan, baik yang dapat dijangkau dengan akal maupun yang hanya diimani dengan kalbu; bukan hanya lahiriah saja, tetapi juga batiniahnya (Mastuhu, 1999: 25).
Sesuai dengan perkembangan masyarakat yang dinamis sebagai akibat kemajuan ilmu pengetahuan dan teknologi, terutama teknologi informasi, maka aktualisasi nilainilai Al-Qur'an menjadi sangat penting. Karena tanpa aktualisasi kitab suci ini, umat Islam akan menghadapi kendala dalam upaya internalisasi nilai-nilai Al-Qur'ani sebagai upaya pembentukan pribadi umat yang beriman, bertaqwa, berkhlak mulia, cerdas, maju dan mandiri.

Secara normatif, tujuan yang ingin dicapai dalam proses aktualisasi nilai-nilai Al-Qur'an dalam pendidikan meliputi tiga dimensi atau aspek kehidupan yang harus dibina dan dikembangkan oleh pendidikan, Pertama, dimensi spiritual, yaitu iman, takwa dan akhlak mulia (yang tercermin dalam ibadah dan mu'amalah). Dimensi spiritual ini tersimpul dalam satu kata yaitu akhlak. Akhlak merupakan alat kontrol psikis dan sosial bagi individu dan masyarakat. Kedua, dimensi budaya yaitu kepribadian yang mantap dan mandiri, tanggung jawab kemasyarakatan dan kebangsaan. Dimensi ini secara universal menitikberatkan pada pembentukan kepribadian Muslim sebagai individu yang diarahkan kepada peningkatan dan pengembangan faktor dasar (bawaan) dan faktor ajar (lingkungan atau miliu), dengan berpedoman pada nilai-nilai keIslaman. Faktor dasar dikembangkan dan ditingkatkan kemampuan melalui bimbingan dan pembiasaan berfikir, bersikap dan bertingkah laku menurut normanorma Islam. Ketiga, dimensi kecerdasan yang membwa kepada kemajuan, yaitu cerdas, kreatif, terampil, disiplin, etos kerja, 
Pembinaan Keberagamaan dan Keilmuan

profesional, inovatif, dan produktif (Said Agil Husin Al-Munawar, 2005: 7-9). Dimensi kecerdasan dalam pandangan psikologi merupakan sebuah proses yang mencakup tiga proses yaitu analisis, kreativitas, dan praktis. Untuk mewujudkan nilainilai al-Qur'an dalam kehidupan diperlukan kurikulum pendidikan Islam yang sesuai dengan tuntutan Islam dan kondisi zaman.

Dalam banyak pembahasan, kesadaran akan pentingnya penanaman nilai-nilai keagamaan memang mendapatkan perhatian serius, hal ini tak lain karena realitas kekinian yang semakin mengkhawatirkan khususnya di kalangan generasi muda. Persoalan yang muncul semakin kompleks karena konteks sosial yang juga rumit untuk dipahami dalam pola fikir mereka. Fenomena tawuran pelajar, kasus-kasus narkoba, kebebasan seksual dan gaya hidup metropolis lainnya semakin dekat dengan generasi muda. Bukan hanya di perkotaan, namun sudah menghilangkan sekat-sekat geografis. Keadaan ini semakin hari semakin merata. Kegelisahan dapat dirasakan, namun akar dari kegelisahan itu masih sulit untuk ditemukan sebagai starting point dalam merangkai kembali jalinan nilai yang memudar dalam dinamika kehidupan modern yang tak terkendali. Agama masih diyakini sebagai solusi dan masih ada dalam benak kejiwaan setiap orang. Tetapi sekat yang muncul dari realitas modern kehidupan semakin menjauhkan sistem nilai dari normanorma keagamaan yang diyakini, dan mengarahkan pola fikir pada pemilahan antara kebutuhan riil (duniawi) dan kebutuhan abstrak (ukhrowi). Inilah tantangan yang dihadapi di masa kini. Lalu bagaimana melangkah dan menentukan arah kebijakan untuk generasi mendatang, sementara sampai hari ini belum mampu menyelesaikan kontradiksi internal pada tataran ideologis yang dianut.

Untuk menghadapi permasalahan di atas, tidak perlu pesimis, tentunya ada solusi yang bisa dilakukan. Salah satunya keberadaan Madrasah Diniyah masih bisa diberdayakan untuk mempasilitasi generasi muda dalam menghadapi tantangan zaman yang semakin kompleks. Ada beberapa hal yang penting untuk dicatat sebagai potensi ideal yang masih dimiliki oleh madrasah diniyah misalnya, pertama, berangkat dari kebutuhan masyarakat, dikelola dan dikembangkan oleh masyarakat serta selalu bergerak dinamis dalam konteks kemasyarakatannya, artinya integritas ideologis madrasah diniyah betul-betul merepresentasikan sebagai gerakan kemasyarakatan yang masih relatif murni dan terlepas dari kepentingan-kepentingan lain seperti ekonomi dan politik misalnya. Kedua, semua itu terjadi karena orisinalitas ide madrasah diniyah yang memang berakar kuat secara historis pada masyarakat. Ketiga, keberpihakan pada masyarakat lemah masih dominan dalam visi kemasyarakatan madrasah, sistem administrasi yang meskipun kurang profesional namun sangat toleran terhadap kondisi ekonomi masyarakatnya, SPP yang ringan atau mungkin tidak ada sama sekali (prinsip keikhlasan), (www.Blogger.com).

Beberapa poin diatas cukuplah untuk kita menyimpulkan bahwa di tengah modernitas kehidupan bangsa kita ada kerinduan pada hilangnya 
norma-norma yang menjadi pedoman hidup kita di masa lalu, spiritualitas, moralitas dan kerukunan adalah tiga landasan hidup yang mulai memudar dan sering menjadi bencana sosial di lingkungan masyarakat. Dengan mengembalikan ketiga nilai tersebut melalui langkah strategis berupa penguatan internal kelembagaan madrasah diniyah, semoga kita bisa kembali meraih apa yang telah hilang dari kesadaran kita dan menjadikannya sebagai karakter pribadi bangsa Indonesia yang moralis, mandiri dan dengan kualifikasi Imtaq dan Iptek sesuai dengan slogan yang selalu kita suarakan. Peran institusi pendidikan Islam baik yang formal maupun non formal, termasuk institusi pendidikan yang dimiliki dan dikelola oleh organisasi/lembaga keislaman, sangat penting. Sumbangan mereka bagi pembentukan karakter anak didik yang moralis, mandiri dan dengan kualifikasi Imtaq dan Iptek, sekaligus nasionalis perlu terus dikembangkan.

Dalam konteks di atas dapat dikemukakan definisi pendidikan Islam, di antaranya yang dikemukakan oleh Ahmad Tafsir, pendidikan Islam adalah bimbingan terhadap seseorang agar ia menjadi Muslim semaksimal mungkin (1995: 32). Maksum Mukhtar memaknai pendidikan Islam merupakan salah salah satu usaha untuk menumbuhkan dan memantapkan kecendrungan tauhid yang telah menjadi fitrah manusia (2001: 30).

Dalam

perkembangan pendidikan selanjutnya banyak orang yang mereduksi makna pendidikan ke dalam proses belajar mengajar yang dilakukan dibangku sekolah. Jika yang terakhir ini dikehendaki, maka sudah terjadi konsekuensi logis di zaman yang serba canggih ini dengan berbagai kemajuan teknologi yang dilahirkan, pendidikan seakan selalu tersisihkan dengan kemajuan ilmu pengetahuan dan tekhnologi. Berdasarkan batasan dan pengertian pendidikan Islam tersebut, secara implisit bisa dipahami bahwa pendidikan Islam adalah sebuah kegiatan pembinaan dan bimbingan yang terencana dan disengaja dalam rangka mencapai kepribadian yang utuh, yakni kepribadian muslim, yang totalitas baik yang berkaitan dengan jasmani, ruhani, akal ataupun moral.Salah satu di antara lembaga pendidikan keislaman yang sifatnya nonformal dan perlu terus dikembangkan adalah Madrasah Diniyah. Dengan dikembangkannya Madrasah Diniyah, diharapkan generasi muda yang berada dalam naungan lembaga ini dapat dijadikan aset nasional yang perlu dijaga dan ditingkatkan kualitasnya, baik kualitas keberagamaannya maupun kualitas keilmuannya sebagai pribadi muslim yang utuh. Setidaknya, jika kualitas lembagalembaga pendidikan seperti Madrasah Diniyah ini meningkat dengan kualitas didalamnya, maka akan meningkat pula prospek lembaga pendidikan Islam dalam mengemban misi nasional mencerdaskan bangsa sekaligus memperkuat dasar-dasar persatuan kebangsaan Indonesia.

Dalam rangka mempertahankan pemahaman nilainilai keislaman dan menghasilkan manusia yang berkualitas, Madrasah Diniyah Attaqwa (MDA) berusaha menjadi wadah untuk pembinaan semangat keberagamaan dan keilmuan generasi muda Desa Cisontrol Kabupaten Ciamis. MDA sebagai salah satu lembaga 
Pembinaan Keberagamaan dan Keilmuan

pendidikan Islam dijadikan wadah untuk melakukan konsolidasi dengan berbagai pihak dan berperan sebagai wadah untuk meningkatkan semangat memperjuangkan ajaran Islam dan semangat dalam menambah wawasan keilmuan generasi muda Desa Cisontrol. Jika dari berbagai sumber menyebutkan bahwa semangat keberagamaan dan keilmuan generasi muda Desa Cisontol menunjukkan hal yang positip, maka diduga profil dan keberadaan MDA mempunyai peran penting, serta pola-pola yang dipakai di MDA menjadi acuan untuk memotivasi generasi muda dalam mengaktualisasikan semangat keberagamaan dan keilmuannya. Maka dalam hal ini memerlukan penelitian lebih lanjut.

\section{Metode}

Penelitian ini menggunakan desain penelitian historis, yaitu suatu desain/metode penelitian yang khusus digunakan dalam penelitian sejarah dengan melalui tahapan tertentu (aalmarusy.blogspot.com). Metode Historis ini, sesuai dengan tujuan penelitian yang sedang dilakukan yaitu untuk mendeskripsikan dan menganilisis peristiwa-peristiwa masa lampau. Desain/metode historis ini bertumpu kepada empat langkah kegiatan, yaitu heuristik, Kritik, interpretasi, dan historiografi (Dudung Abdurahman, 2007: 63). Heuristik (teknik pengumpulan sumber), kritik (verifikasi untuk memperoleh keabsahan sumber), interpretasi (analisis), historiografi (penulisan, pemaparan hasil penelitian sejarah yang dilakukan). Masing-masing langkah dalam penelitian ini lebih jelasnya akan diuraikan dalam pengolahan dan analisis data selanjutnya.

Sumber data dalam penelitian ini termasuk dalam tahapan heuristik. Tahapan heuristik ini adalah tahapan untuk menghimpun dan mengumpulkan sumber inpormasi yang berhubungan dengan obyek yang diteliti. Dalam tahapan ini peneliti akan menghimpun sumber data yang didapatkan, berhubungan dengan Madrasah Diniyah Attaqwa, kemudian diklasifikasikan menjadi suatu katagori yaitu sumber primer dan sekunder, baik berupa lisan, tulisan maupun benda.

Berdasarkan fokus penelitian ini, maka jenis data dalam penelitian ini adalah data kualitatif, merupakan deskripsi yang luas dan berlandaskan kokoh, serta memuat penjelasan proses-proses yang terjadi dalam lingkup setempat. Moleong mendefinisikan pendekatan kualitatif ini sebagai penelitian yang bermaksud untuk memahami fenomena tentang apa yang dialami oleh subjek penelitian misalnya perilaku, persepsi, motivasi, tindakan, dan lain-lain, secara holistik, dan dengan cara deskripsi dalam bentuk kata-kata dan bahasa, pada suatu konteks khusus yang alamiah dan dengan memanfaatkan berbagai metode alamiah (2007: 6). Menurut Lofland, sebagaimana dikutip Moleong (2007: 112), sumber data utama dalam penelitian kualitatif adalah kata-kata dan tindakan selebihnya adalah data tambahan seperti dokumen dan lainnya. Kata-kata dan tindakan orang-orang yang diamati atau diwawancarai, merupakan jenis data utama. Jenis data utama merupakan sumber tertulis. Sedangkan data kedua dicatat melalui catatan tertulis, 
atau melalui perekam, foto dan dokumen.

Teknik pengumpulan data merupakan salah satu langkah untuk mendapatkan data dari obyek yang diteliti sebelum mengambil kesimpulan akhir dari suatu penelitian yang dilakukan. Adapun teknik pengumpulan data dalam penelitian ini, adalah wawancara (mengadakan dialog/komunikasi secara langsung dengan sumber data/responden, dokumentasi (mengumpulkan dan mempelajari sejumlah dokumen yang berkaitan dengan pembinaan semangat keberagamaan dan keilmuan generasi muda), dan studi kepustakaan (mengkaji dan mempelajari bukubuku yang relevan dengan masalah yang diteliti).

Setiap perisiwa yang telah terjadi, pasti meninggalkan jejakjejak yang dapat dijadikan bukti sebagai peristiwa-peristiwa yang terjadi di masa lampau. Peristiwaperistiwa tersebut merupakan obyek penelitian sejarah. Berdasarkan jejak-jejak itulah terdapat pesan yang ditinggalkan oleh peristiwa-peristiwa tersebut. Dari hasil penelusuran sejarah itu, dimaksudkan untuk membuat rekonstruksi masa lampau secara sistematis dan objektif dengan cara mengumpulkan, mengevaluasi, memverifikasi serta mensistensikan bukti-bukti untuk menegakkan masalah, dan selanjutnya dilakukan penelitian. Dalam pengolahan dan analisis data dalam penelitian ini, sesuai dengan metode penelitian yang sudah dikemukakan adalah menggunakan metode Historis. Dimana tahapan penelitian historis itu sesuai yang sudah dikemukakan oleh Dudung Abdurrahman adalah heuristik, kritik, interpretasi, dan historiografi (Dudung Abdurahman, 2007: 63).

Tahapan heuristik ini adalah tahapan untuk menghimpun dan mengumpulkan sumber inpormasi yang berhubungan dengan obyek yang diteliti. Dalam tahapan ini peneliti akan menghimpun sumber data yang didapatkan, kemudian diklasifikasikan menjadi suatu katagori yaitu sumber primer dan sekunder, baik berupa lisan, tulisan maupun benda. Sumber yang sudah didapatkan melalui tahapan heuristik tidak bisa langsung digunakan sebagai sumber sejarah, apalagi yang akan dijadikan sumber primer. Sumber-sumber tersebut harus diuji terlebih dahulu. Pengujian itu dilakukan melalui metode kritik. Kritik adalah tahapan atau kegiatan meneliti sumber, informasi, jejak, secara kritis, atau dengan kata lain menyeleksi sumber-sumber yang telah didapatkan. Tahapan kritik dibagi menjadi dua yaitu kritik ekstern dan kritik intern. Setelah selesai dalam tahapan kritik, selanjutnya adalah tahapan interpretasi. Dalam tahapan ini seorang sejarawan berusaha untuk menginterpretasi atau menafsirkan sumber-sumber yang telah terkumpul menjadi satu keseluruhan yang harmonis. Langkah terakhir adalah historiografi yaitu cara penulisan, pemaparan atau pelaporan hasil penelitian sejarah yang telah dilakukan. Layaknya penelitian ilmiah, penulisan hasil penelitian sejarah itu handaknya dapat memberikan gambaran yang jelas mengenai proses penelitian dari awal sampai akhir. 
HASIL PENELITIAN DAN PEMBAHASAN

Profil Madrasah Diniyah Attaqwa Desa Cisontrol Kabupaten Ciamis Tahun 1983-1989

Madrasah Diniyah Attaqwa (MDA) berdiri tahun 1983, atas bimbingan ketua seksi dakwah Majelis Ulama (MU) Kecamatan Rancah yang sekaligus ketua Majelis Ulama Desa Cisontrol (Yulis Hadiyati R: Wawancara). Pada waktu itu (tahun 1983), MDA merupakan Madrasah Diniyah yang pertama kali berdiri di Desa Cisontrol. Keberadaan MDA di Desa Cisontrol sepertinya membawa nuansa baru dengan lingkungan saat itu. Bangunan yang dijadikan tempat untuk belajar MDA berada di Desa Cisontrol, tepatnya berada di sekitar daerah Kebon Kawung, Rt 02/Rw 02 Mandalagiri, Cisontrol, Rancah, Ciamis, Jawa Barat.

Sementara pelaksanaan belajarnya dimulai dari hari Senin sampai hari Kamis, dimulai jam 13.00 sampai jam 17.00. Tapi untuk kelas yang lebih besar (tingkat SMP), terkadang mereka belajar sampai waktu shalat Isya, terutama kalau di sekolah ada tugas-tugas atau menjelang ujian mereka belajar. Bahkan terkadang mereka menginap di MDA sambil tidak lupa ditanamkan pelaksanaan shalat tahajud bersama.

Jika melihat karakteristik Madrasah Diniyah di atas, maka MDA termasuk jenis Pendidikan Diniyah Takmiliyah (suplemen) yang berada di tengah masyarakat dan tidak berada dalam lingkaran pengaruh pondok pesantren. Pendidikan diniyah jenis ini betulbetul merupakan kreasi dan swadaya masyarakat, yang diperuntukkan bagi anak-anak yang menginginkan pengetahuan agama di luar jalur sekolah formal. Dengan semangat yang tinggi, mereka dibina dan dibimbing untuk menjadi seorang manusia yang beriman, bertaqwa dan berakhlaq Al-Kariimah. Untuk pembiayaan sarana dan prasarana MDA, termasuk untuk honor guru yang mengajar, betul-betul merupakan keihlasan dan panggilan jiwa. Guru-guru yang mengajar semuanya tanpa pamrih, ikhlas, gigih, berani dan semangat dalam mendidik. Kalau pun ada semacam SPP dari santrinya, itu betul-betul dipergunakan untuk kepentingan sarana dan prasarana Diniyah.

MDA dari tahun ketahun terus berkembang, dari mulai resmi berdiri tahun 1983 sampai tahun 1989 MDA merupakan Madraasah Diniyah yang aktif sebagai lembaga pendidikan Islam non-formal yang mandiri di lingkungan Desa Cisontrol. Sejak tahun 1989 setiap kampung yang berada di lingkungan Desa Cisontrol mendirikan Madrasah Diniyah masing-masing. Termasuk MDA pun terpecah menjadi dua tempat, yaitu yang berada di Lingkungan Kampung Mandalagiri dan Kampung Harja Mukti. Perlu diketahui pula bahwa MDA mempunyai struktur organisasi yang diikat dalam satu ikatan "Keluarga Besar Madrasah Diniyah Attaqwa (KBMDA)". Kalau di sekolah formal ikatan siswa itu dibentuk dalam wadah "Organisasi Siswa Intera Sekolah (OSIS)", sedangkan di MDA untuk mengikat santrinya dibentuk KBMDA.

Muatan pokok mata pelajaran ialah salah satu atau sekumpulan bahan kajian, yang diajarkan kepada santri untuk mencapai tujuan pendidikan di Madrasah Diniyah yang tersebar disemua tingkat. Setiap 
tingkat memiliki kedalaman yang berbeda-beda sesuai dengan perkembangan psikologi dan pengalaman siswa. Adapun muatan pokok mata pelajaran yang diberikan di MDA merupakan poin penting yang menjadi pertimbangan dalam pembinaan keberagamaan dan keilmuan bagi generasi muda Desa Cisontrol. Materi-materi pelajaran yang merupakan muatan pokok di MDA itu diantaranya adalah AlQur'an, Tafsir, Hadits dan ilmu hadits, sejarah islam, B. Arab, fiqih dan lain-lain (Aep Kusnawan: Wawancara). Berdasarkan data yang ada dalam buku rapor salah satu santri yang pernah belajar di MDA, tercantum beberapa materi yaitu, AlQur'an (Hafidz dan Kiroat), Tafsir, Hadits, Tauhid, Fiqih (Ibadah dan Syari'ah), Sejarah Islam, Bahasa Arab, Kaligerafi, Akhlaq dan Do'a. Ditambah ada satu materi lagi bagi kelas yang sudah besar /SMP , diberikan

materi Kemuhammadiyahan. Materi yang ada dalam buku Rapor sama dengan yang tercantum dalam Ijazah dan daftar nilai gabungan MDA.

Selain materi pokok yang diberikan, MDA juga mempunyai program yang lain dalam memupuk semangat keberagamaan dan keilmuan, diantaranya mengenalkan tentang seni terutama Seni Qasidah (Musik Islami) dan Seni Kaligerafi (Seni menulis huruf Arab hias). Dalam bidang ilmu Ekonomi, santri belajar mempraktekan dagang yang dibina dalam koprasi. Santri mengelola koprasi dengan berdagang menjual kebutuhan alat tulis menulis dan makanan ringan seadanya. Bidang Olah raga (terutama Sepak Bola dan Volly Ball), mereka rutin melakukan latihan olah raga setiap hari Minggu dan menjalin silaturahmi dengan Diniyah yang ada di luar Desa Cisontrol dengan pertandingan persahabatan. Dalam menjalin hubungan sosial dengan Masyarakat, santri juga sering melaksanakan kegiatan membersihkan lingkungan bersamasama dengan masyarakat sekitar. Baik membersihkan jalan-jalan, selokan, pemakaman umum dan sarana-sarana lainnya.

Peranan Madrasah Diniyah Attaqwa dalam Membina Semangat Keberagamaan dan Keilmuan Generasi Muda Desa Cisontrol Kabupaten Ciamis Tahun 19831989

Madrasah Diniyah memiliki poin penting untuk diusung sebagai kekuatan dalam menggalang kepercayaan diri bangsa. Ide-ide dasar kehidupan bangsa, spritualitas yang termanifestasi dalam prikehidupan sosial dan kemasyarakatan, menghargai konteks kemajemukan, semuanya telah dan pernah dimiliki oleh masyarakat Indonesia.

$\begin{array}{crr}\text { Madrasah } & \text { Diniyah banyak } \\ \text { memberikan } & \text { kekuatan dalam }\end{array}$
melangkah menghadapi tantangan zaman yang begitu kompleks. Apa yang didapat dari Diniyah merupakan dasar terutama dalam masalah aqidah sampai saat ini (Endang Darmawan: Wawancara). Senakal-nakalnya anak yang sudah pernah belajar di MDA tidak akan senakal yang lain, sebab baginya apa yang sudah didapat dari MDA bisa membentengi diri kita dari persoalan-persoalan terutama dikalangan remaja sebagai generasi penerus. MDA banyak berperan dalam membimbing generasi muda pada saat itu, bahkan sampai sekarang sangat terasa manfaatnya. 
Pembinaan Keberagamaan dan Keilmuan

Kalau saja pada waktu itu tidak bergabung dengan MDA, mungkin dirinya sudah terbawa dengan pergaulan remaja yang tidak menentu (YAyan Sugiyanto: Wawancara).

MDA yang berada di lingkungan Desa Cisontrol Kecamatan Rancah Kabupaten Ciamis, merupakan lembaga pendidikan Islam Nonformal yang mampu menanamkan nilai-nilai intelektualitas, keimanan dan keterampilan di kalangan anak didiknya. Hal itu terbukti dengan semangat keberagamaan dan keilmuan generasi muda yang pernah mengemban pendidikan di MDA Desa Cisontrol mampu memberikan teladan dalam semangat menjalankan ajaran agamanya dan bersaing dengan dunia luar di berbagai bidang keilmuan.

Keberhasilan pendidikan agama bagi anak-anak tidak cukup diukur hanya dari segi seberapa jauh anak itu menguasai hal-hal yang bersifat kognitif atau pengetahuan tentang ajaran agama atau ritus-ritus keagamaan semata. Justru yang lebih penting adalah seberapa jauh tertanam nilai-nilai keagamaan tersebut dalam jiwa anak, dan seberapa jauh pula nilai-nilai itu mewujud nyata dalam tingkah laku dan budi pekertinya sehari-hari (Nurholis Madjid, 1997: 132). Sebab pendidikan agama tidak dapat dipahami secara terbatas hanya kepada pengajaran agama. Ungkapan tersebut sejalan dengan peranan MDA dalam membina semangat keberagamaan generasi muda yang belajar di MDA untuk mengaktualisasikan dan mengamalkan ajaran-ajaran Islam berdasarkan al-Qur'an dan Sunah Rasul. Banyak diantara mereka yang dengan keyakinan dan semangat juang yang tinggi, mencoba membangun diri dan lingkungannya dengan suasana religius.

Salah satu indikasi dari semangat keberagamaan mereka bangun adalah ketika lembagalembaga pendidikan umum tidak memberlakukan siswanya untuk memakai jilbab, justru mereka yang belajar di MDA menjadi pionir, teladan dalam mengawali pemakaian jilbab di sekolah-sekolah mereka. Banyak tantangan-tantangan yang dihadapi diawal perjuangan menegakkan Syari'at Islam itu, tetapi tidak membuat mereka gentar dan mundur, justru yang muncul adalah semangat mengobarkan api perjuangan menegakan ajaran Islam (Titin Sumiati: Wawancara).

Di sisi lain keberadaan MDA memberikan peran juga dalam membina semangat untuk meningkatkan kualitas keilmuan. Mereka yakin dengan janji Allah dalam QS. Al-Mujadalah ayat 11, untuk meninggikan derajat orangorang yang berilmu. Firman Allah tersebut dijadikan pegangan dan motivasi untuk terus maju dalam menuntut ilmu dan mengamalkannya dalam kehidupan sehari-hari. MDA merupakan wadah untuk memberikan pelayanan kepada generasi muda dalam meningkatkan kualitas keilmuan di berbagai bidang.

Semangat keberagamaan mereka ternyata sejalan dengan semangat keilmuannya. Salah satu bukti yang ada, banyak alumnialumni MDA yang termotivasi untuk melanjutkan pendidikannya ke jenjang yang lebih tinggi. Keilmuan yang mereka ambil berpariasi, sesuai dengan minat dan bakatnya masingmasing. Ada yang mengambil jalur agama, ada pula yang mengambil 
jalur umum.Ketika mereka berada dalam komunitas pendidikan umum (tidak dibawah lembaga pendidikan keagamaan) mereka sudah memiliki modal dasar agama/aqidah yang cukup kuat ketika mereka menimba ilmu di MDA. Jalur pendidikan formal memasuki SMA ini, rata-rata mereka tempuh ke luar Desa Cisontrol, sehingga mau tidak mau rutinitas belajar di MDA pun terhenti. Walaupun rutinitas belajar mereka di MDA (karena melanjutkan pendidikan formalnya) terhenti, namun ikatan emosional diantara sesama keluarga besar MDA tetap terjalin dan dibangun komunikasi yang berkelanjutan. Bahkan ketika mereka pulang ke kampung halamannya, sudah menjadi panggilan jiwa bagi mereka untuk menyempatkan diri datang ke MDA, menjalin silaturrahmi dan berbagi pengalaman baru dengan adikadiknya. Jika dilihat perjuanganperjuangan dan keberhasilan generasi muda yang pernah belajar di MDA khususnya dalam rentang waktu tahun 1983-1989, baik dalam semangat keberagamaan maupun keilmuannya, menunjukkan betapa besar peranan MDA di Desa Cisontrol dalam membina generasi mudanya, sehingga mampu mengaktualisasikan ilmu-ilmu yang didapat di MDA dalam kehidupan sehari-hari. Walaupun peranan MDA hanya salah satu faktor saja dalam mendukung keberhasilan mereka, tapi keberadaan MDA betul-betul memberikan pelajaran yang tiada ternilai dan tidak akan terlupakan dalam memaknai hidup dan kehidupan ini. Sudah barang tentu masih banyak faktor lain yang mampu menghantarkan mereka ke arah keberhasilan dan kesuksesan sampai saat ini. Tapi paling tidak keberadaan MDA memberikan peran penting dalam menghantarkan mereka sehingga bisa sampai seperti sekarang.

Pola Pembinaan Madrasah Diniyah Attaqwa dalam Membina Semangat Keberagamaan dan Keilmuan Generasi Muda Desa Cisontrol Kabupaten Ciamis Tahun 19831989.

MDA sebagai lembaga pendidikan Islam, semua pijakannya didasarkan kepada Al-Qur'an, AlSunnah dan Ijtihad (Yulis Hadiyati R: Wawancara). Melihat beberapa teori pendidikan yang dikemukakan di atas, hal itu sesuai dengan polapola pengembagan pendidikan yang dilakukan di MDA, khususnya dalam rangka membina semangat keberagamaan dan keilmuan generasi muda di Desa Cisontrol. Pola-pola tersebut diantaranya :

\section{Pola}

Pembinaan

\section{Aqidah/Tauhid}

Pola pembinaan pertama dan utama yang dilakukan di MDA adalah membina aqidanya/Tauhidnya (Yulis HAdiyati R: Wawancara). Aqidah merupakan salah satu materi pokok yang diberikan. Diharapkan dengan penanaman aqidah sebagai modal yang utama, generasi muda Desa Cisontrol tidak akan terbawa oleh arus zaman yang tidak menentu. Mereka sudah dibentengi oleh aqidah yang kuat berdasarkan Al-Qur'an, Al-Sunnah dan Ijtihad para Ulama.

\section{Pola Berjenjang/Kaderisasi}

Pola Berjenjang/Kaderisasi dalam pelaksanaan pembelajarannya santri yang sudah senior mengajar kepada yang masih yunior, atau kelas tinggi mengajar kepada kelas rendah. Pola ini merupakan solusi dalam menghadapi santri MDA yang banyak. Karena jumlah santri yang 
banyak tidak mungkin dipegang hanya oleh satu guru. Logikanya, kalau saja misalnya ada santri 80 orang dan hanya dipegang oleh satu guru, dengan memakai pola konfensional tentu tidak akan tertangani dan akan merasa cape. Makanya dengan pola berjenjang/kaderisasi, akan ada multi efek yang kemudian berimbas (Aep Kusnawan: Wawancara). Diantara efek yang muncul adalah semua santri bisa belajar, santri yang lebih senior ketika membimbing yang yunior dia juga mengamalkan apa yang sudah diterima dari seniornya sambil menghafal, senior menjadi memiliki wibawa dihadapan yunior, yunior menghargai/ajrih ke senior, walaupun siapa yang menyangka kalau sekarang anak SMP bisa mendidik anak SD.

Pola penanamannya seperti di atas, memang ditanamkan oleh guru, bahwa ini pada dasarnya refresentasi guru. Jadi kalau SMP mengajar SD, itu sama dari guru, karena sama ilmunya dari guru. Tapi yang membedakannya guru menitipkan kepada yang lebih senior, kemudian untuk disampaikan lagi kepada yang Yunior. Itulah yang disebut oleh alumni MDA yang lain pola penyampaian materi yang berulangulang Wiseu Dinihari: Wawancara). Hampir semua alumni yang diwawancara mengakui pola ini betul-betul terasa manfaatnya.

\section{Pola Ruhul Jihad}

Pola Ruhul Jihad adalah pola yang semat-mata ikhlas panggilan jiwa dalam rangka jihad di jalan Allah. Memang pola ini dipengaruhi juga oleh guru yang pada waktu itu tidak ada kepentingan apa-apa. Istilahnya, kalau saja berbuat sesuatu itu bermanfaat bagi orang lain, kenapa tidak mengamalkan ilmu yang sudah dimiliki. Selain faktor guru utama pada waktu itu belum berkeluarga, ditambah lagi konsentrasi untuk memajukan MDA betul-betul fokus, tanpa dipengaruhi oleh kebutuhan-kebutuhan yang sifatnya pribadi.

\section{Pola Tauladan/Pigur Guru}

Tauladan yang dimaksud adalah contoh yang dimunculkan dari seorang guru betul-betul menjadi tauladan. Baik itu berupa penampilan, perhatian yang diberikan, ilmu yang diberikan, dan lain-lain. Yang jelas apa yang dimunculkan dari seorang guru betul-betul menjadi figur sentral untuk digugu dan ditiru. Guru sebagai tauladan yang digugu dan ditiru, memang ada faktor yang mempengaruhinya. Pada waktu itu belum banyak tantangan, belum banyak menggunakan alat komunikasi seluler, tidak banyak nongton televisi, dan lain-lain. Jadi apa yang didapat di MDA ternyata banyak mempengaruhi mereka, baik dalam mengenal masalah keagamaan, maupun mengenal pengetahuan dunia luar. Apa yang dikatakan oleh guru ditaati dan dituruti. Mereka masih bersih, belum banyak terkontaminasi oleh faktor yang lain, ditambah dasar aqidahnya yang sudah kuat.

\section{Pola Kebersamaan dan} Kekeluargaan

Pola ini ditanamkan dalam rangka menguatkan ikatan kebersamaan dan keluarga dikalangan anggota KBMDA. Tidak ada sekat pemisah sama sekali, baik antara senior dan Yunior, maupun antara guru dan muridnya. Mereka saling membutuhkan, saling menghargai, saling menyayangi, sejalan sepenanggungan dalam kebersamaan yang kuat. 
Kebahagiaan dan kesedihan ditanggung bersama, semuanya saling mengisi.

Pola-pola di atas merupakan pola yang dikembangkan oleh MDA dalam membina semangat keberagamaan dan keilmuan generasi mudan Desa Cisontrol. Kalau saja pola-pola itu diterapkan di Madrasah Diniyah sekarang, tentunya akan ada nuansa lain yang mampu menguatkan semangat keberagamaan dan keilmuan generasi muda ditengah-tengah tantangan zaman. Dengan berkaca kepada pola pembinaan yang dipakai di MDA ternyata banyak manfaat dan keberhasilan yang bisa diraih. Perkembangan Madrasah Diniyah yang sekarang ada sepertinya sudah banyak terkontaminasi oleh berbagai faktor, maka keberhasilan Madrasah Diniyah kurang begitu nampak. Walaupun disisi lain, Madrasah Diniyah masih bisa dilihat dan dijadikan alternatif orang tua untuk menitipkan anak-anaknya agar belajar ilmu agama.

Semoga dengan langkahlangkah yang dikembangkan oleh MDA, bisa memberikan masukan dan gambaran bagi Madrasah Diniyah yang lain untuk lebih maju dan nampak keberhasilannya dalam membina generasi muda yang berakhlakul karimah dan menguasai keilmuan diberbagai bidang. Amin.

\section{SIMPULAN}

Setelah penulis melakukan penelitian terhadap "Pembinaan Keberagamaan dan Keilmuan Generasi Muda Desa Cisontrol Kabupaten Ciamis Tahun 19831989, kemudian melakukan analisis yang didukung oleh teori-teori yang terdapat pada bab sebelumnya, maka dapat diambil kesimpulan sebagai berikut:

Pertama, Gambaran umum Madrasah Diniyah Attaqwa, merupakan Madrasah Diniyah yang pertama kali berdiri di Desa Cisontrol yang penuh dengan kesederhanaan, tapi memiliki segudang prestasi dan keberhasilan terutama dalam membina semangat keberagamaan dan keilmuan generasi muda di Desa Cisontrol. Kedua, Peranan Madrasah Diniyah Attaqwa banyak membawa keberhasilan Generasi Muda Desa Cisontrol dalam mengaktualisasikan rasa keberagamaan dan keilmuannya. MDA telah memberikan spirit dalam memperjuangkan dan menegakkan ajaran Islam, menambah keyakinan dalam aqidah, memberi motivasi untuk berani dan pantang menyerah dalam keadaan apa pun. Terbukti dalam proses belajar mengajar di MDA, mereka tidak hanya sebatas menerima teori-teori tapi sekaligus mampu mempraktekkan dan mengaktualisasikannya dalam kehidupan sehari-hari. Apa yang mereka dapat sewaktu menimba ilmu di MDA ternyata menjadi modal dasar dalam menjalani kehidupan sekarang. Mereka bisa berhasil sampai sekarang karena peranan MDA yang tidak bisa dilupakan. Ketiga, Keberhasilan Madrasah Diniyah Attaqwa dalam membina semangat keberagamaan dan keilmuan generasi muda di Desa Cisontrol tidak terlepas dari Pola pola yang dikembangkan di MDA. Pola-pola tersebut diantaranya penanaman aqidah, pola berjenjang/kaderisasi, ruhul jihad, tauladan/figur guru, pola kebersamaan dan kekeluargaan. Dengan menerapkan pola-pola tersebut, maka tumbuh semangat 
Pembinaan Keberagamaan dan Keilmuan Generasi Muda di Madrasah Diniyah Attaqwa Desa Cisontrol Kabupaten Ciamis Tahun 1983-1989

keberagamaan dan keilmuan yang tinggi di kalangan generasi muda.

Keunggulan MDA dalam pembinaan semangat keberagamaan dan keilmuan generasi muda di Desa Cisontrol memberikan masukan kepada Madrasah Diniyah yang lain dan sekaligus merupakan solusi yang bisa dimanfaatkan dalam pembinaan generasi muda. Keunggulan itu berupa profil Madrasah Diniyah yang bebas dari unsur kepentingan pribadi dan politik, peranan Madrasah Diniyah yang betul-betul mampu membina generasi mudanya dalam semangat keberagamaan dan keilmuan, serta pola-pola yang dipakai dalam pembinaan semangat keberagamaan dan keilmuan generasi muda, yang dampaknya bisa dirasakan bagi pribadi mereka masing-masing.

\section{DAFTAR PUSTAKA}

Afif Muhammad, Dari Teologi ke Ideologi Telaah atas Metode dan Pemikiran Teologi Sayyid Quthb, Bandung : Pena Merah, 2004.

Ahmad Tafsir (ed), Epistemologi untuk Ilmu Pendidikan Islam, Bandung : Fak. Tarbiyah IAIN SGD Bandung, 1995.

Andi Hakim Nasution, dkk, Pendidikan Agama dan Akhlak Bagi Anak dan Remaja, Jakarta: Logos, 2001.

Dudung Abdurahman, Metodologi Penelitian Sejarah, Jogjakarta: Ar-ruzz Media Group, 2007.

http://www.ziddu.com/donwnload/13 726376/instrumen
Madin.rar.html, diunduh pada 20 Agustus 2016.

http://

achakim.blogspot.com/feeds/ post/default, diunduh pada 25 Agustus 2016.

http://id.shvoong.com/humanities/phi losophy/2069565-pengertianilmu/\#ixzz1yiPQmQzG, diunduh 30 Agustus 2016.

http://

achakim.blogspot.com/feeds/

post/default, diunduh 05 September 2016.

http://www.Blogger.com/profile/181 48928786159132851, diunduh 05 September 2016.

http//:

aalmarusy.blogspot.com/.../m etode-penelitian-sejarah..., diunduh 10 September 2016.

Karel A. Steenbrink, Pesantren Madrasah Sekolah Pendidikan Islam dalam Kurun Modern, (Jakarta : LP3ES, 1994.

Lexy J Moleong, Metodologi Penelitian Kualitatif, Bandung : Remaja Rosdakarya, 2007.

Maksum Mukhtar, Madrasah dan Sejarah Perkembangannya, Ciputat : Logos Wacana Ilmu, 2001.

Muhammad Irfan \& Mastuki HS, Teologi Pendidikan Tauhid sebagai Paradigma Pendidikan Islam, Jakarta : Friska Agung Insani, 2000. 
Nurholis Madjid, Masyarakat Religius, Jakarta: Paramadina, 1997.

Said Agil Husin Al-Munawar, Aktualisasi Nilai-Nilai Qur'ani dalam Sistem Pendidikan Islam, Jakarta : Ciputat Press, 2005.

\section{Sumber Lisan}

Dra.Yulis Hadiyati Rohana, M.Pd selaku pendiri, pembina, pengelola dan sekaligus guru Madrasah Diniyah Attaqwa Desa Cisontrol (Wawancara : Minggu, 28 April 2012, di rumah kediamannya, Cisontrol).

Titin Sumiati, alumni Madrasah Diniyah Attawqa Desa Cisontrol tahun 1988 (Wawancara : Kamis, 26 April 2012, di rumah kediamannya, Ciguruwik Bandung).
Aep Kusnawan, M.Ag, alumni Madrasah Diniyah Attaqwa Desa Cisontrol tahun 1987 (Wawancara : Sabtu, 5 Mei 2012, di rumah kediamannya, Manisi Bandung).

Wiseu Dinihari, alumni Madrasah Diniyah Attaqwa Desa Cisontrol tahun 1989 (Wawancara : Minggu, 6 Mei 2012).

Endang Darmawan, alumni Madrasah Diniyah Attaqwa Desa Cisontrol tahun 1985 (Wawancara : Sabtu, 12 Mei 2012).

H. Yayan Sugiyanto, alumni Madrasah Diniyah Attaqwa Desa Cisontrol tahun 1986 (Wawancara : Sabtu, 12 Mei 2012). 